\title{
Symposium review: Strategies to improve the efficiency and profitability of heifer raising*
}

\author{
P. S. Erickson, ${ }^{1} \dagger$ ๑ J. L. Anderson, ${ }^{2} \oplus$ K. F. Kalscheur, ${ }^{3} \odot$ G. J. Lascano, ${ }^{4} \oplus$ M. S. Akins, ${ }^{5} \oplus$ \\ and A. J. Heinrichs ${ }^{6}$ (1) \\ ${ }^{1}$ Department of Agriculture, Nutrition, and Food Systems, University of New Hampshire, Durham 03824 \\ ${ }^{2}$ Dairy and Food Science Department, South Dakota State University, Brookings 57007 \\ ${ }^{3}$ US Dairy Forage Research Center, USDA-Agricultural Research Service, Madison, WI 53706 \\ ${ }^{4}$ Animal and Veterinary Sciences Department, Clemson University, Clemson, SC 29634 \\ ${ }^{5}$ Department of Dairy Science, University of Wisconsin-Madison, Marshfield 54449 \\ ${ }^{6}$ Department of Animal Science, The Pennsylvania State University, University Park 16802
}

\section{ABSTRACT}

Regional Research Project NC-2042 has a main objective to study calf and heifer nutrition. Within this objective, feeding the postweaned heifer is considered a major priority to improve the profitability and sustainability of US dairy farms. Through optimizing nutrient utilization by precision feeding, using alternative feeds, high-fiber diets, and feed additives, this research group has worked to enhance dairy heifer nutrition. Research has focused on precision feeding heifers and incorporating high- and low-fiber diets into this system of feeding. This is accomplished by meeting the nutrient needs of the heifer for a desired rate of growth while enhancing total-tract nutrient digestibility, reducing waste and improving profitability. High-fiber forages have been studied as a means of controlling ad libitum dry matter intakes and thus weight gain in heifers. These results provide producers with a means of feeding heifers while reducing costs. Similarly, utilizing alternative feedstuffs in heifer diets has also been a major research area for this group including comprehensive research on distillers co-products, and new protein sources such as camelina and carinata meals. Results indicated that these products can be satisfactorily incorporated into heifer diets. Studying feed additives has also been a function of the research group. Research with Ascophyllum nodosum and cinnamaldehyde indicated that calves find these additives unpalatable and that supplementing cin-

Received August 6, 2019.

Accepted December 18, 2019.

*Presented as part of the "Production, Management, and the Environment Symposium: Profitability and Sustainability" at the ADSA Annual Meeting, Cincinnati, Ohio, June 2019.

†Corresponding author: peter.erickson@unh.edu namaldehyde to postweaned heifers showed no benefit. However, sodium butyrate and yeast supplementation proved to be beneficial in the growth and feed efficiency of heifers. Research from this group has an effect on heifer feeding, resulting in new information that can aid in the sustainability of dairy farms. This review will focus on the area of postweaned heifer nutrition.

Key words: precision feeding, high-fiber forage, coproduct feed, feed additive

\section{INTRODUCTION}

Dairy heifers are an integral part of any dairy farm and have been found to account for $>12 \%$ of total dairy farm expenses with feed consisting of more than $60 \%$ of that cost (Gabler et al., 2000). As with any aspect of a dairy farm, some dairy farms are more efficient and cost effective at raising heifers than others. An analysis of heifer costs that looked at efficiency of heifer raising (Heinrichs et al., 2013) found that calving heifers younger than 24 mo and having $>88 \%$ milk production from first-lactation animals as compared with the mature herd mates were the 2 single efficient components of a heifer raising system. In a separate study, it was found that increasing or decreasing the age at calving of a dairy herd by 1 mo of age altered heifer raising costs by roughly $5 \%$ for each month (Tozer and Heinrichs, 2001).

The way heifers are raised affects their future ability to be productive. Raising heifers over $900 \mathrm{~g} / \mathrm{d}$ during the prepubertal period has been shown to decrease first lactation milk production in a meta-analysis (Zanton and Heinrichs, 2005), and this decrease is similar to what was previously determined with different breeds of animals, differing production levels, and optimal ADG (Zanton and Heinrichs, 2005). A method to measure growth in dairy heifers in lieu of a scale is a weight tape, and this has been validated as an accurate way of 
estimating BW in modern Holstein heifers (Heinrichs et al., 2017).

The objective of this symposium paper was to review and describe research conducted by members of the NC-2042 project (Management Systems to Improve the Economic and Environmental Sustainability of Dairy Enterprises) on how heifers are fed and managed. These investigations includes how precision feeding dairy heifers, and the inclusion of high-fiber forages, alternative feedstuffs, and feed additives contribute to raising profitable and sustainable dairy heifers in the United States. The way that heifers are fed and managed has been the subject of research by several universities and remains a strong objective of continued investigation of raising profitable and sustainable dairy heifers in the United States.

\section{PRECISION FEEDING}

An important nutritional aspect related to efficiency that has been researched by the NC-2042 in growing ruminants recently is the concept of precision feeding. In the last 2 decades, the term "precision feeding" has been used to refer to programs that provide heifers with the correct amount of nutrients for adequate economic growth without affecting future performance and milk production (Zanton and Heinrichs, 2007; Koch et al., 2017). According to White and Capper (2014), precision nutrition enhances productivity and performance by more accurately meeting the nutrient requirements of each individual animal or pen of animals. Under precision feeding conditions, diets are isocaloric and isonitrogenous. However, the rate of energy provision can vary because of different forage-to-concentrate ratios (F:C), the use of ingredients with different concentrations of structural and nonstructural carbohydrates, and several other factors (Lascano and Heinrichs, 2011). The feeding strategies used during pre- and postpubertal growth of the dairy heifer directly influence lactation performance. Therefore, it has been imperative to investigate how to provide nutrients from different ingredients in a precise manner to dairy heifers that otherwise are commonly fed low-cost and low-quality ingredients, typically ad libitum. An alternative to this system is precision feeding where nutrients are provided to fulfill specific requirements for growth, without affecting mammary development and age at first calving. Experiments using precision feeding have investigated the effects of different dietary $\mathrm{F}: \mathrm{C}$ ratios, with varying structural and nonstructural carbohydrates, protein degradabilities, digestion kinetics, and interactions among these factors. A prepubertal ADG of approximately 800 $\mathrm{g} / \mathrm{d}$ (range $700-900 \mathrm{~g} / \mathrm{d}$ ) was reported as optimal to enhance lactation performance in Holstein dairy cows (Zanton and Heinrichs, 2005). This target ADG was instrumental to investigate nutrient concentrations that allow efficient growth to enhance animal performance. It was reported that heifers were more feed efficient when they were limited in intake as compared with heifers fed ad libitum (Hoffman et al., 2007; Zanton and Heinrichs, 2009b; Lascano et al., 2009). Hoffman et al. (2007) noted that limit-feeding gravid heifers improved feed efficiency by $18.8 \%$ when DMI was reduced by $10 \%$ and reduced manure DM excretion without negative effects on growth or first lactation performance. Similar results were also observed by Zanton and Heinrichs, (2007) who also showed a linear improvement in $\mathrm{CP}, \mathrm{OM}$, and NDF digestibility as heifers went from 2 to $1.25 \%$ BW DMI (Zanton and Heinrichs, 2008). Further work showed that fiber and starch digestibility was reduced when heifers were offered low versus high forage diets (Lascano and Heinrichs, 2011). Feeding trials demonstrated a significant improvement in DM digestibility when high forage or high concentrate diets were limit-fed to 7 - to 9-mo-old or 19- to 21-mo-old heifers (Zanton and Heinrichs, 2016).

Zanton and Heinrichs (2008) also showed that as heifers increase intake, total manure and wet fecal output increases 2.54 times faster than DMI. This observation illustrates some of the other environmental aspects of limit-feeding dairy heifers.

Nutrient digestibility coefficients were significantly increased for low forage diets under precision feeding, and these increases resulted in improved feed efficiency, reducing DMI significantly when compared with ad libitum feeding. A common concern when feeding low forage diets is the possible negative effects on health and rumen fermentation; however, when limiting the amount of readily available carbohydrates, rumen $\mathrm{pH}$ was minimally or not affected (Lascano et al., 2015b). It was demonstrated that limit-fed rations had a decreased rate of passage in heifers, which led to the improved DM digestibility (Pino and Heinrichs, 2018).

The strategic use of structural and nonstructural carbohydrates such as starch or soluble fiber has been observed as a possible alternative when these nutrients are provided precisely (Lascano et al., 2012a). In the study of Lascano et al. (2012a), soluble fiber replaced starch but provided similar NFC dietary concentrations and resulted in similar digestibility coefficients. Interestingly, under these controlled feeding conditions, direct-fed live yeast improved feed digestion and enhanced rumen fermentation, especially in high concentrate diets (Lascano et al., 2012a, 2015b). Moreover, the incorporation of refractory fibrous ingredients has shown positive effects on microbial protein flow and $\mathrm{N}$ 
retention due to modified digestion kinetics observed when using limited intakes (Lascano et al., 2012a; Koch et al., 2017).

Precision feeding high and low forage diets provokes an increased digesta retention time, which often results in higher digestibility and modified digestion kinetics. Passage rates $\left(\boldsymbol{k}_{\mathrm{p}}\right)$ are higher in growing dairy heifers when compared with lactating cows due to limited rumen capacity. However, particulate and fluid $k_{\mathrm{p}}$ can be reduced when feed intakes are controlled; moreover, low dietary forage concentration can reduce $k_{\mathrm{p}}$ further and increase digestibility coefficients ruminally and postruminally (Ding et al., 2015; Lascano et al., 2016). More specifically, if low forage diets are used, total intake is reduced yet similar energy and protein concentration are provided to meet the formerly mentioned targeted ADG (Lascano and Heinrichs, 2011). This modification from ad libitum systems has consistently resulted in improved digestibility coefficients, but further adjustments are needed related to other dietary concentrations of nutrients in rations (Suarez Mena et al., 2015; Lascano et al., 2016; Koch et al., 2017).

Suarez-Mena et al. (2013) observed that chewing activities were modified by $\mathrm{F}: \mathrm{C}$ and distillers grains with solubles (DDGS) addition. High F:C resulted in longer eating time and higher weight and volume of rumen digesta. Whereas DDGS increased ruminating time in precision-fed dairy heifers, low forage diets increased nutrient utilization with DDGS (precision-fed to dairy heifers up to a $14 \%$ inclusion rate with $\mathrm{N}$ retention potentially being reduced with greater concentrations of DDGS; Suarez-Mena et al., 2015). Moreover, Lascano et al. (2016) concluded that low fiber levels in lowand high-forage diets increased utilization of nutrients under precision feeding conditions when provided with high rumen degradable protein. Concurrently, Zanton and Heinrichs (2016) reported that heifers limit-fed high-energy diets increased digestibility and $\mathrm{N}$ retention and that younger animals are more responsive to this feeding strategy. To complement the information collected related to precision feeding, Lascano et al. (2015a) reported that dietary fiber modulated ammonia emissions differently on extremely high $(\sim 80 \%)$ and low $(\sim 20 \%)$ forage diets and that methane concentration was correlated with odor intensity. These results strongly support that the use of high-forage, high-fiber diets under precision feeding conditions accelerate passage rates, which results in a reduction in retention time with its concurrent effect on nutrient digestion and utilization (Lascano et al., 2016; Pino et al., 2018).

Another important target to meet when using precision feeding is protein intake. It was observed that an $\mathrm{N}$ intake of $1.67 \mathrm{~g}$ of $\mathrm{N} / \mathrm{kg}$ of $\mathrm{BW}^{0.75}$ enhances nutrient utilization regardless of dietary $\mathrm{F}: \mathrm{C}$ (Zanton and
Heinrichs, 2009a). This targeted $\mathrm{N}$ intake allowed to further investigations into protein degradability. Lascano et al. (2016) and Koch et al. (2017) reported that protein degradability needs to be considered to enhance $\mathrm{N}$ utilization when using differing $\mathrm{F}: \mathrm{C}$ and increasing concentrations of dietary fiber. Based on the mentioned results, high RDP can improve performance when using diets with high fermentation potential, whereas RUP supplementation is needed as more fibrous ingredients are used in diets precisely fed to dairy heifers.

Finally, Suarez-Mena et al. (2019) showed that mineral apparent digestibility/absorption and retention can be affected by F:C (e.g., $\mathrm{Mg}, \mathrm{P}$, and $\mathrm{S}$ resulted in increased retention in high-forage diets and reduction/ no effect in low-forage diets) and that this factor needs to be considered when using minerals in dairy heifers precision fed to achieve a targeted ADG. From the results presented here, it can be concluded that precision feeding is a valid option to use a vast number of ingredients based on their nutritional characteristics to enhance feed efficiency and performance of dairy heifers. Precision feeding dairy heifers can be accompanied by modifying $\mathrm{F}: \mathrm{C}$ according to specific needs of the production system. Under these conditions, animals are provided with energy and nutrients adjusted to allow the animal to reach a targeted ADG. This allows the strategic inclusion of ingredients and the reduction of DMI, resulting in enhanced efficiency of nutrient (starch, protein, fiber) fractions utilization. Further research is needed on the effects of lipid dietary incorporation and more specific nutrient constituents (e.g., AA, fatty acids, sugars, and soluble and structural carbohydrates) that will additionally enhance growing heifer performance.

\section{USE OF HIGH-FIBER FORAGES FOR FEEDING DAIRY HEIFERS}

Corn silage and high-quality grass or alfalfa forages are common forage ingredients on dairy farms. These work well for heifers up to about 12 mo of age depending on forage quality. However, dairy heifers greater than 12 mo of age have lower energy needs than younger dairy heifers due to greater intake potential and feeding the correct diet energy is important to control weight gain in the range of 0.8 to $1.0 \mathrm{~kg} / \mathrm{d}$ (Hoffman, 1997; Zanton and Heinrichs, 2005). Bred and pregnant heifers (>12 mo of age) require approximately 58 to $62 \%$ TDN or $2.1 \mathrm{Mcal} / \mathrm{kg}$ of DM depending on the environment, whereas corn silage (68.8\% TDN; NRC, 2001) is usually well above this level. The desire to use corn silage in heifer diets due to its high yields and lower cost has led to the evaluation of higher-fiber forages such as warmseason perennials, straw, corn stover, alfalfa stems, 
and sorghum forages, which can be used to dilute diet energy and restrict intakes when combined with corn silage and alfalfa silage. Higher-fiber diets not only lower energy content but also reduce intakes because dairy heifers eat approximately $1 \%$ of $\mathrm{BW}$ as NDF each day (Hoffman et al., 2008). The use of high-fiber, low-energy forages allows for ad libitum feeding and possibly lower feed costs due to reduced intakes and lower forage production/purchase costs. This concept is another method to control feed and energy intake in bred/pregnant heifers, as compared with the use of precision-fed diets discussed previously.

Perennial warm-season grasses are an ideal forage source for pregnant heifers due to high fiber content. Heifers used in the following summary of studies were between 15 and 20 mo of age and either bred or confirmed pregnant. Coblentz et al. (2012) evaluated the feeding of the warm season perennial grass eastern gamagrass. Typically, the NDF content is 70 to $75 \%$ of DM, CP 5 to $8 \%$ DM, and TDN 50 to $55 \%$ when harvested in September. In a heifer feeding study, eastern gamagrass was included in the diet at $0,9,18$, and $27 \%$ of diet DM to increase NDF from 40 to $49 \%$ and decrease TDN from 68 to $61 \%$. Inclusion of gamagrass led to lower DMI and energy intakes and thus more ideal daily gains $(1.09,1.03,0.95$, and $0.85 \mathrm{~kg} / \mathrm{d}$ for 0 , 9,18 , and $27 \%$ gamagrass inclusion). A unique finding was that heifers readily consumed the gamagrass silage with minimal or no sorting. To further evaluate this forage compared with other high-fiber roughages, Coblentz et al. (2015) fed heifers either a high-quality control diet (67\% TDN and $13.9 \% \mathrm{CP})$ or 1 of 3 diets with a diluted forage: (1) eastern gamagrass silage, (2) chopped wheat straw, or (3) chopped corn stover. Diluted diets were balanced to have similar energy $(59 \%$ TDN) and protein content (13.8\% CP). Diets were fed for minimal refusals (1-3\% refusals) so that heifers consumed almost the entire diets. The heifers fed diets with high-fiber forages had 1 to $1.5 \mathrm{~kg}$ lower DMI and more optimal gains than the control diet $(1.16,0.98$, 0.97 , and $0.79 \mathrm{~kg} / \mathrm{d}$ for control, gamagrass, stover, and straw diets, respectively). Diet sorting was greatest for the corn stover diet with straw being intermediate compared with the control and gamagrass diets, which had minimal sorting similar to previous work. To minimize sorting when feeding less palatable roughages (straw or stover), it is recommended to decrease the roughage particle size to less than $5 \mathrm{~cm}$, add water to decrease the diet DM content to 45 to $50 \%$, and feed for minimal refusals.

The use of alfalfa stems (forage left after stripping of leaves) may also be of use in dairy heifer diets to lower energy and increase fiber content. Su et al. (2017) fed heifers a control corn silage/alfalfa silage diet (13.1\%
CP, $40 \%$ NDF, $65 \%$ TDN) diluted with either alfalfa stem baled silage $(12.6 \% \mathrm{CP}, 46 \% \mathrm{NDF}, 59 \% \mathrm{TDN})$ or chopped wheat straw $(12.6 \% \mathrm{CP}, 43 \% \mathrm{NDF}, 62 \%$ TDN). The diluted diets led to lower intakes (11.3, 10.3 , and $10.4 \mathrm{~kg}$ of $\mathrm{DM} / \mathrm{d}$ for control, stemlage, and straw, respectively) and more optimal gains (1.32, 0.96, and $1.04 \mathrm{~kg}$ of gain/d for control, stemlage, and straw, respectively) than the control diet.

Sorghums [forage sorghum, sorghum-sudangrass (SS), and sudangrass] are another high-fiber, lowerenergy option to use in heifer diets. Conventional (non-BMR) and photoperiod-sensitive sorghums have an ideal fiber and energy content to blend in pregnant heifer diets with a moderate- to high-quality haylage or possibly a protein byproduct (distillers grain or gluten feed) when forage supplies are low. Harvesting strategy affects yield with a single harvest having 1.5 to 2 times greater yield than a 2-cut system (Remick et al., 2016). A plot study conducted in Central Wisconsin showed yields for conventional forage sorghum and SS planted in early to mid-June in $38-\mathrm{cm}$ rows and harvested one time in October or early November were 12.4 to 17.3 $\mathrm{t}$ of $\mathrm{DM} /$ ha (Remick et al., 2016). Neutral detergent fiber content was 55 to $60 \%$ and protein was 5 to $7 \%$. Li et al. (2019) compared feeding heifers a control diet diluted with low-quality grass hay at $25 \%$ of diet DM or diets with conventional or photoperiod-sensitive SS silage at $50 \%$ of the diet to reduce the energy and increase NDF content. Energy content of the diets was similar (60-61\% TDN), but the NDF content of the diets was higher for the SS silage diets (55\% NDF) than the diet diluted with grass hay $(48 \% \mathrm{NDF})$. This led to lower intakes by heifers fed the SS diets (10.9, 9.27 , and $9.0 \mathrm{~kg}$ of $\mathrm{DM} / \mathrm{d}$ for control, conventional SS, and photoperiod-sensitive SS, respectively) and more optimal gains (0.89 and $0.94 \mathrm{~kg} / \mathrm{d}$ for conventional and photoperiod-sensitive SS, respectively) compared with heifers fed the diet diluted with grass hay $(1.11 \mathrm{~kg} / \mathrm{d})$. Minimal differences in intake or growth were observed between heifers fed the conventional or photoperiodsensitive SS diets. However, SS diets were more sortable than the control due to longer stem particles with a shorter chop length recommended to minimize sorting.

\section{FEEDING ALTERNATIVE FEEDSTUFFS TO GROWING DAIRY HEIFERS}

Alternative feedstuffs have been extensively evaluated by the NC2042 group to determine how they can be successfully incorporated in growing heifer rations. These feedstuffs have been evaluated in diets formulated to maintain the $800 \mathrm{~g} / \mathrm{d}$ of ADG needed for lean growth, but not compromise mammary development (Zanton and Heinrichs, 2005). 
Wet distillers grains with solubles (WDGS) is a good source of CP, fiber, and fat and can be an excellent, less expensive feedstuff for growing heifer diets. Energy supplied as fermentable fiber and fat from WDGS ensiled in combination with soyhulls was compared with starch from corn grain was evaluated in growing dairy heifers (Anderson et al., 2009). Wet distillers grains with solubles were mixed and ensiled with soyhulls at a ratio of $70 \%$ WDGS and 30\% soyhulls on an as-fed basis before the start of the study. The WDGS-soyhull blend replaced corn and soybean meal at 0, 24.4, and $48.7 \%$ of the diet (DM basis). The inclusion of the blend increased dietary concentrations of NDF, ADF, and ether extract, but decreased concentrations of starch and nonfibrous carbohydrates. Heifers were fed for ad libitum intake. While DMI decreased as the amount of the WDGS-soyhull blend increased in the diets, ADG did not differ among diets and was greater than the recommended rate. Body frame measures, including withers height, hip height, heart girth, and body length, were also similar for all treatments. As more fat and protein provided by the WDGS pass through the rumen undegraded, a greater extent of these nutrients are digested and absorbed in the small intestine. Anderson et al. (2009) concluded that replacing one-half or all of the traditional concentrate mix with a blend of WDGS and soyhulls in diets maintained performance and improved feed efficiency for growing dairy heifers.

Since WDGS may provide more protein and energy than required by a growing dairy heifer, diluting this energy and protein by mixing WDGS with a low-quality forage such as corn stalks would be a way to maximize the inclusion of WDGS in dairy heifer diets without overfeeding protein and energy. Anderson et al. (2015d) evaluated the intake and digestibility of WDGS ensiled with cornstalks when fed to growing dairy heifers. Two parts WDGS were ensiled with 1 part cornstalks (as-fed basis) in silage bags and fed to heifers. The combination of WDGS and corn stalks were ensiled either untreated or with a preservative. Heifers were fed one of the following diets: (1) control diet with $70 \%$ hay and $30 \%$ corn and soybean meal concentrate mix, (2) 99\% untreated WDGS-cornstalk blend with 1\% mineral mix, or (3) 99\% treated WDGS-cornstalk blend with $1 \%$ mineral mix. No differences were observed for DMI or ADG of heifers across diets. Total-tract digestibility of CP, NDF, and ADF was similar for heifers fed the control and untreated WDGS-cornstalk blend, but was greater for heifers fed the treated WDGS-cornstalk blend. Overall, the study demonstrated that dairy heifers fed WDGS blended with a crop residue can be just as successful as traditional heifer rations using corn and soybean meal.
Further evaluating the effect of dietary fat provided by DDGS in diets of growing heifers, Anderson et al. (2015b) hypothesized that feeding fat and fermentable fiber instead of starch as the energy source may maintain heifer growth while altering metabolic profile. Heifers were fed (1) a control diet containing ground corn and soybean products, (2) a low-fat diet containing low-fat, high-protein DDGS and ground corn, or (3) a high-fat diet using traditional DDGS. The highfat diet contained $4.8 \%$ fat compared with $2.8 \%$ fat in the control and low-fat diets (on a DM basis), but diets were similar in energy content. Heifers were limitfed at $2.45 \%$ of BW. Dry matter intakes, BW, ADG, and gain-to-feed ratio did not differ because of dietary treatments. In addition, body frame measurements and body condition scores were similar among treatments. Utilizing fat from DDGS in replacement of starch from corn as a dietary energy source did not influence growth performance or negatively affect nutrient digestion (Anderson et al., 2015b), but it did alter blood concentrations of fatty acids and cholesterol and time of puberty (Anderson et al., 2015a). Heifers from this study were followed for the first $120 \mathrm{~d}$ of lactation and it was determined that milk production was similar for heifers fed the high-fat diet compared with heifers fed the control diet containing corn and soybean feedstuffs, whereas the heifers fed the low-fat DDGS diet resulted in increased milk yields compared with heifers fed the control diets (Anderson et al., 2015c). Consequently, it was concluded that when feeding prepubertal heifers, dietary fat from DDGS can replace starch from corn grain without negatively affecting future lactation performance.

With increased interest in evaluating reduced-fat DDGS via a solvent extraction process, Schroer et al. (2014) compared feeding a control diet that contained corn and soybean meal in the concentrate mix to diets with 20\% conventional DDGS and 20\% reduced-fat DDGS to growing Holstein heifers. Frame measurements, DMI, ADG, and feed efficiency were not affected by treatment. This study demonstrated that growing heifer diets can successfully include high levels of either reduced-fat DDGS or traditional DDGS without affecting growth performance.

The addition of DDGS in limit-fed dairy heifer diets was further evaluated in an experiment by Manthey et al. (2016). Prepubertal dairy heifers were fed one of the following diets: (1) 30\% DDGS with the diet fed at $2.65 \%$ of BW, (2) $40 \%$ DDGS with the diet fed at $2.50 \%$ of BW, and (3) 50\% DDGS with the diet fed at $2.35 \%$ of BW. The rest of the diet consisted of grass hay and mineral mix. Limit-feeding diets containing up to $50 \%$ of the diet as DDGS maintained growth performance of 
dairy heifers based on growth measurements, BW, and ADG. Limit-feeding diets with greater concentrations of DDGS improved gain: feed and total-tract digestibility of DM, OM, and CP. Forage can be replaced with DDGS up to $50 \%$ of the diet (on a DM basis) in limit-fed rations while maintaining heifer growth performance. Heifers from this study were followed into the first $90 \mathrm{~d}$ of lactation and it was determined that milk production and milk composition was similar for heifers formerly fed DDGS at $30 \%, 40 \%$, or $50 \%$ of the diet DM (Manthey and Anderson, 2017). When feeding prepubertal heifers, heifers can be limit-fed diets with increasing inclusion of DDGS without detrimentally affecting postpubertal growth or milk production in their first lactation.

Since the inclusion of high-fiber feedstuffs may decrease diet digestibility, the use of a limit-feeding strategy where nutrient-dense diets are fed to meet but not exceed nutrient requirements may reduce DMI, but potentially increase nutrient digestibility, can result in maintaining growth performance in dairy heifers. Manthey and Anderson (2018) evaluated growth performance and nutrient digestibility of dairy heifers fed a limit-fed corn and soybean feedstuff diet compared with a DDGS diet when grass hay was fed ad libitum. Both concentrate mixes were limit-fed at $0.8 \%$ of BW. No differences in frame measurements, BW, ADG, or feed efficiency with small shifts in metabolites were determined between treatments. Producers can limit-feed a DDGS-based concentrate mix when providing grass hay ad libitum to maintain heifer growth and ADG compared with a traditional concentrate mix with corn and soybean feedstuffs.

In addition to distillers grains, several nontypical feedstuffs have been evaluated in growing dairy heifer diets as alternative protein sources. Camelina and carinata are both alternative oilseeds being researched for the development of biofuels, biopesticides, and bioplastics. Co-products of this research are camelina meal and carinata meal, which could be used as livestock feedstuffs (Paula et al., 2019). However, both oilseeds are noted for having higher concentrations of glucosinolates compared with canola meal, although they are different types of glucosinolates. These glucosinolates in camelina and carinata can be bitter, be goitrogenic, depress growth, and potentially damage the liver and kidneys. These characteristics have limited their investigation as feedstuffs in ruminant diets. The objective of these research studies was to determine whether these feedstuffs could be successfully included in growing dairy heifer diets without resulting in negative growth performance.

Lawrence et al. (2016) compared the inclusion of camelina meal to linseed meal and DDGS at $10 \%$ of the diet (on a DM basis) for growing dairy heifers. Diets were individually limit-fed at $2.65 \%$ of $\mathrm{BW}$ on a DM basis. While frame measurements were similar for heifers fed all treatments, the heifers fed the camelina meal diet resulted in a tendency for lesser ADG, which consequently decreased the gain-to-feed ratio compared with heifers fed the linseed meal diet. This is commonly observed with diets formulated with oilseed meals containing glucosinolates. Most metabolites and nutrient utilization among treatments were also similar. Overall, results demonstrated that camelina meal can be formulated into growing dairy heifer diets at $10 \%$ of the diet (on a DM basis) and maintain comparable growth performance to diets formulated with DDGS and linseed meal.

Rodriguez-Hernandez and Anderson (2018) investigated the inclusion of cold-pressed carinata meal with DDGS at $10 \%$ of the diet for growing dairy heifers. Diets were individually limit-fed at $2.65 \%$ of $\mathrm{BW}$ on a DM basis. Frame measurements, DMI, BW, ADG, and gain-to-feed ratio were similar between treatments. Total-tract digestibility of DM and NDF were decreased for heifers fed carinata meal compared with heifers fed DDGS. However, these differences did not influence growth performance. Initial results demonstrated that carinata meal is a potential protein and energy source for growing dairy heifers when included at $10 \%$ of the diet DM. Additional research investigating the use of camelina meal and carinata meals is needed to determine how they can be best used as alternative feedstuffs in the diets of growing dairy heifers and dairy cattle at other life stages.

In summary, distillers grains can be included in heifer diets under a variety of feeding strategies. Distillers grains can replace some or all of the corn and soybean meal from growing heifer diets while maintaining growth performance. Blending WDGS with forages or low-quality crop residues, which have nutrient profiles that can complement each other, can result in high inclusion levels. Because of its high energy content and high palatability, it is recommended that distillers grains should be limit-fed or further diluted with high-bulk, low-energy feeds to prevent excessive BW gains. Furthermore, camelina and carinata meals, both coproducts of the renewable fuels industry, have shown potential as alternative protein sources for growing dairy heifers. Further research is needed to develop feeding strategies to best use these feed resources.

\section{FEED ADDITIVES}

Feed additives have a variety of uses in heifer diets, including modifying performance or controlling diseases such as coccidiosis. With concern about bacterial resis- 
tance, research within this research group has focused on attempting to find alternatives to antibiotics for use in heifer diets. The use of mineral alternatives such as Ascophyllum nodosum (kelp) meal has also been evaluated in the feeding behavior of heifers. Two studies were conducted to evaluate the taste preferences of calves to feed additives (Erickson et al., 2012; Chapman et al., 2016). Both studies used a sequential elimination methodology where calves are provided with a choice of a feed with an additive designed to test the effects of taste and smell (Nombekela et al., 1994). Kelp meal is a common feed additive used in the northeast United States. It has a distinct odor and is thought to stimulate the umami taste. In the first experiment (Erickson et al., 2012), 0, 30, or $60 \mathrm{~g}$ of kelp meal (Ascophyllum nodosum) was added to calf starter fed to six 6-wk-old, recently weaned calves. Results indicated that calves do not prefer kelp, with treatments preferred in the following order: 0,60 , and $30 \mathrm{~g}$. Calves will eat starter grain containing kelp but do not prefer it when given a choice.

Essential oils have been evaluated in many experiments with mixed results. These products are used as performance modifiers. Chapman et al. (2016) evaluated the taste preference of 5 levels of the essential oil cinnamaldehyde using heifers fed an $80 \%$ forage diet. Six 3-mo-old heifers $(95 \pm 10.8 \mathrm{~kg})$ were used to test $0,1,2,3$, or $4 \mathrm{mg} / \mathrm{kg}$ cinnamaldehyde addition to their diet. Results indicated that calves do not prefer cinnamaldehyde, but will consume feed with cinnamaldehyde added to it.

In an experiment to evaluate cinnamaldehyde or monensin, eighty-four 13-wk-old Holstein heifers were divided into 12 pens with 7 heifers per pen and fed 1 of 4 treatments (control, $1 \mathrm{mg}$ of monensin $/ \mathrm{kg}$ of BW, $1 \mathrm{mg}$ of cinnamaldehyde $/ \mathrm{kg}$ of $\mathrm{BW}$, or $2 \mathrm{mg}$ of cinnamaldehyde/kg of BW; Chapman et al. (2017). The $70-d$ study had 3 pens per treatment. Heifers were fed a high-forage diet of ad libitum alfalfa/grass hay and 2.21 $\mathrm{kg} / \mathrm{d}$ of a commercial pellet with whole shelled corn along with $908 \mathrm{~g}$ of corn meal carrier mixed with the respective treatment per day. Results indicated that no effects of treatment on growth, feed efficiency, blood metabolites, or fecal coccidia. Results of this study showed no benefits of these additives compared with control.

Rice et al. (2019) evaluated sodium butyrate (SB) addition to postweaned heifer diets. They used a randomized complete block design to evaluate 4 levels of SB $(0,0.25,0.50$, or $0.75 \mathrm{~g} / \mathrm{kg}$ of BW) on growth, intake, feed efficiency, and coccidia counts. Forty 13-wkold Holstein heifers were used in this 14-wk study. The diet contained $67.5 \%$ forage, $15.8 \% \mathrm{CP}$, and $41 \% \mathrm{NDF}$. Results indicated that heifers fed SB tended to have a greater final BW and were more feed efficient. Also, the $0.25 \mathrm{~g} / \mathrm{kg}$ treatment had the lowest coccidia count over the experiment. Results of this study indicated that SB tended to improve heifer growth and had some efficacy against coccidiosis.

\section{CONCLUSIONS}

As part of the NC2042 Multi-state project titled "Management Systems to Improve the Economic and Environmental Sustainability of Dairy Enterprises," considerable advances have been made in improving nutritional efficiency and profitability of raising dairy heifers. Precision feeding postpubertal dairy heifers has been demonstrated to optimize growth performance and nutrient utilization. In addition, alternative feedstuffs and additives can be used in growing heifer rations to improve the efficiency of nutrient utilization. Further research conducted by the NC2042 group and by others on the incorporation of high-fiber forages, alternative feedstuffs, and feed additives will help further delineate ways of feeding heifers for profitable and sustainable dairy farms.

\section{ACKNOWLEDGMENTS}

The authors have not stated any conflicts of interest.

\section{REFERENCES}

Anderson, J. L., K. F. Kalscheur, J. A. Clapper, G. A. Perry, D. H. Keisler, A. D. Garcia, and D. J. Schingoethe. 2015a. Feeding fat from distillers dried grains with solubles to dairy heifers: II. Effects on metabolic profile. J. Dairy Sci. 98:5709-5719. https://doi.org/ 10.3168/jds.2014-9163.

Anderson, J. L., K. F. Kalscheur, A. D. Garcia, and D. J. Schingoethe. 2015b. Feeding fat from distillers dried grains with solubles to dairy heifers: I. Effects on growth performance and total-tract digestibility of nutrients. J. Dairy Sci. 98:5699-5708. https://doi .org/10.3168/jds.2014-9162.

Anderson, J. L., K. F. Kalscheur, A. D. Garcia, and D. J. Schingoethe 2015c. Short communication: Feeding fat from distillers dried grains with solubles to dairy heifers: III. Effects on posttrial reproductive and lactation performance. J. Dairy Sci. 98:5720-5725. https://doi.org/10.3168/jds.2014-9164.

Anderson, J. L., K. F. Kalscheur, A. D. Garcia, D. J. Schingoethe, D. P. Casper, and D. H. Kleinschmit. 2015d. Ensiling characteristics of distillers wet grains with corn stalks and determination of the feeding potential for dairy heifers. Prof. Anim. Sci. 31:359-367. https://doi.org/10.15232/pas.2015-01386.

Anderson, J. L., K. F. Kalscheur, A. D. Garcia, D. J. Schingoethe, and A. R. Hippen. 2009. Ensiling characteristics of wet distillers grains mixed with soybean hulls and evaluation of the feeding value for growing Holstein heifers. J. Anim. Sci. 87:2113-2123. https://doi .org/10.2527/jas.2008-1607.

Chapman, C. E., R. G. Cabral, K. M. Aragona, and P. S. Erickson. 2016. Short communication: Cinnamaldehyde taste preferences of post-weaned dairy heifers. J. Dairy Sci. 99:3607-3611. https://doi .org/10.3168/jds.2015-10582.

Chapman, C. E., H. Chester-Jones, D. Ziegler, J. A. Clapper, and P. S. Erickson. 2017. Effects of cinnamaldehyde or monensin on per- 
formance of weaned Holstein dairy heifers. J. Dairy Sci. 100:17121719. https://doi.org/10.3168/jds.2016-11893.

Coblentz, W. K., P. Hoffman, N. Esser, and M. Bertram. 2012. Using eastern gamagrass to construct diets that limit intake and caloric density for dairy replacement heifers. J. Dairy Sci. 95:6057-6071. https://doi.org/10.3168/jds.2012-5686.

Coblentz, W. K., N. Esser, P. Hoffman, and M. Akins. 2015. Growth performance and sorting characteristics of corn silage-alfalfa haylage diets with or without forage dilution offered to replacement Holstein dairy heifers. J. Dairy Sci. 98:8018-8034. https://doi.org/ 10.3168/jds.2015-9491.

Ding, L. M., G. J. Lascano, and A. J. Heinrichs. 2015. Effect of precision feeding high- and low-quality forage with different rumendegradable protein levels on nutrient utilization by dairy heifers. J. Anim. Sci. 93:3066-3075. https://doi.org/10.2527/jas.2014-8260.

Erickson, P. S., S. P. Marston, M. Gemmel, J. Deming, R. G. Cabral, M. R. Murphy, and J. I. Marden. 2012. Short communication: Kelp taste preferences by dairy calves. J. Dairy Sci. 95:856-858. https:/ /doi.org/10.3168/jds.2011-4826.

Gabler, M. T., P. R. Tozer, and A. J. Heinrichs. 2000. Development of a cost analysis spreadsheet for calculating the costs to raise a replacement dairy heifer. J. Dairy Sci. 83:1104-1109. https://doi .org/10.3168/jds.S0022-0302(00)74975-7.

Heinrichs, A. J., B. S. Heinrichs, C. M. Jones, P. S. Erickson, K. F. Kalscheur, T. D. Nennich, B. J. Heins, and F. C. Cardoso. 2017. Short communication: Verifying Holstein heifer heart girth to body weight prediction equations. J. Dairy Sci. 100:8451-8454. https:// doi.org/10.3168/jds.2016-12496.

Heinrichs, A. J., C. M. Jones, S. M. Gray, P. A. Heinrichs, S. A. Cornelisse, and R. C. Goodling. 2013. Identifying efficient dairy heifer producers using production costs and data envelopment analysis. J. Dairy Sci. 96:7355-7362. https://doi.org/10.3168/jds.2012-6488.

Hoffman, P. C. 1997. Optimum body size of Holstein replacement heifers. J. Anim. Sci. 75:836-845. https://doi.org/10.2527/1997 $.753836 \mathrm{x}$

Hoffman, P. C., K. Weigel, and R. Wernberg. 2008. Evaluation of equations to predict dry matter intake of dairy heifers. J. Dairy Sci. 91:3699-3709. https://doi.org/10.3168/jds.2007-0644.

Hoffman, P. C., C. R. Simson, and M. Wattiaux. 2007. Limit feeding of gravid Holstein heifers: Effect on growth, manure nutrient excretion, and subsequent early lactation performance. J. Dairy Sci. 90:946-954. https://doi.org/10.3168/jds.S0022-0302(07)71578-3.

Koch, L. E. N. A., N. A. Gomez, A. Bowyer, and G. J. Lascano. 2017. Precision-feeding dairy heifers a high rumen undegradable protein diet with different proportions of dietary fiber and forage to concentrate ratios. J. Anim. Sci. 95:5617-5628. https://doi.org/10 $.2527 /$ jas2017.1974.

Lascano, G. J., and A. J. Heinrichs. 2011. Effects of feeding different levels of dietary fiber through the addition of corn stover in nutrient utilization of dairy heifers precision-fed high and low concentrate diets. J. Dairy Sci. 94:3025-3036. https://doi.org/10.3168/ jds.2010-3831.

Lascano, G. J., A. J. Heinrichs, R. R. Gary, P. A. Topper, R. C. Brandt, A. Adviento-Borbe, and E. E. Fabian. 2015a. Effects of forage-to-concentrate ratio and dietary fiber manipulation on gas emissions and olfactometry from manure of Holstein heifers. J. Dairy Sci. 98:1928-1937. https://doi.org/10.3168/jds.2014-8633.

Lascano, G. J., A. J. Heinrichs, and J. M. Tricarico. 2012a. Substitution of starch by soluble fiber and Saccharomyces cerevisiae dose response on nutrient digestion and blood metabolites for precisionfed dairy heifers. J. Dairy Sci. 95:3298-3309. https://doi.org/10 $.3168 /$ jds.2011-5047.

Lascano, G. J., A. J. Heinrichs, and J. M. Tricarico. 2015b. Saccharomyces cerevisiae live culture affects rapidly fermentable carbohydrates fermentation profile in precision-fed dairy heifers. Can. J. Anim. Sci. 95:117-127. https://doi.org/10.4141/cjas-2014-104.

Lascano, G. J., L. E. Koch, and A. J. Heinrichs. 2016. Precision-feeding dairy heifers different levels of dietary fiber and high rumen degradable protein diet and differing levels of dietary fiber: Effects on nutrient utilization and N efficiency. J. Dairy Sci. 99:7175-7190.
Lascano, G. J., M. Velez, J. M. Tricarico, and A. J. Heinrichs. 2012b. Short communication: Nutrient utilization of fresh sugarcane-based diets with slow-release nonprotein nitrogen addition for control-fed dairy heifers in the tropics. J. Dairy Sci. 95:370-376. https://doi .org/10.3168/jds.2011-4275.

Lascano, G. J., G. I. Zanton, F. X. Suarez-Mena, and A. J. Heinrichs. 2009. Effect of limit feeding high and low concentrate diets with Saccharomyces cerevisiae on digestibility and on dairy heifer growth and first-lactation performance. J. Dairy Sci. 92:51005110. https://doi.org/10.3168/jds.2009-2177.

Lawrence, R. D., J. L. Anderson, and J. A. Clapper. 2016. Evaluation of camelina meal as a feedstuff for growing dairy heifers. J. Dairy Sci. 99:6215-6228. https://doi.org/10.3168/jds.2016-10876.

Li, L., N. M. Esser, R. K. Ogden, W. K. Coblentz, and M. S. Akins. 2019. Comparison of feeding diets diluted with sorghum-sudangrass silage or low-quality grass on nutrient intake and digestibility and growth performance of Holstein dairy heifers. J. Dairy Sci. 102:9932-9942. https://doi.org/10.3168/jds.2018-16168.

Manthey, A. K., and J. L. Anderson. 2017. Short communication: Feeding distillers dried grains in replacement of forage in limit-fed dairy heifer rations: Effects on post-trial performance. J. Dairy Sci. 100:3713-3717. https://doi.org/10.3168/jds.2016-12041.

Manthey, A. K., and J. L. Anderson. 2018. Growth performance, rumen fermentation, nutrient utilization, and metabolic profile of dairy heifers limit-fed distillers dried grains with ad libitum forage. J. Dairy Sci. 101:365-375. https://doi.org/10.3168/jds.2017 $-13239$.

Manthey, A. K., J. L. Anderson, and G. A. Perry. 2016. Feeding distillers dried grains in replacement of forage in limit-fed dairy heifer rations: Effects on growth performance, rumen fermentation, and total-tract digestibility of nutrients. J. Dairy Sci. 99:7206-7215. https://doi.org/10.3168/jds.2015-10785.

Nombekela, S. W., M. R. Murphy, H. W. Gonyou, and J. I. Marden. 1994. Dietary preferences in early lactation cows as affected by primary tastes and some common feed flavors. J. Dairy Sci. 77:23932399. https://doi.org/10.3168/jds.S0022-0302(94)77182-4.

NRC. 2001. Nutrient Requirements of Dairy Cattle. 7th rev. ed. National Academy Press, Washington DC.

Paula, E. M., L. G. da Silva, V. L. N. Brandao, X. Dai, and A. P. Faciola. 2019. Feeding canola, camelina, and carinata meals to ruminants. Animals (Basel) 9:704. https://doi.org/10.3390/ani9100704.

Pino, F., L. K. Mitchell, C. M. Jones, and A. J. Heinrichs. 2018. Comparison of diet digestibility, rumen fermentation, rumen rate of passage, and feed efficiency in dairy heifers fed ad-libitum versus precision diets with low and high quality forages. J. Appl. Anim. Res. 46:1296-1306. https://doi.org/10.1080/09712119.2018 1498788 .

Remick, E., H. Su, W. Coblentz, and M. Akins. 2016. Yield and nutritive value of photoperiod sensitive sorghum and sorghum-sudangrass in central Wisconsin. J. Dairy Sci. 99(E-Suppl. 1):308.

Rice, E. M., K. M. Aragona, S. C. Moreland, and P. S. Erickson. 2019. Supplementation of sodium butyrate to post-weaned heifer diets: Effects on growth performance, nutrient digestibility, and health. J. Dairy Sci. 102:3121-3130. https://doi.org/10.3168/jds .2018-15525.

Rodriguez-Hernandez, K., and J. L. Anderson. 2018. Evaluation of carinata meal as a feedstuff for growing dairy heifers: Effects on growth performance, rumen fermentation, and total-tract digestibility of nutrients. J. Dairy Sci. 101:1206-1215. https://doi.org/ 10.3168/jds.2017-13584.

Schroer, R. C., T. D. Nennich, T. S. Dennis, M. M. Schutz, S. S. Donkin, and D. Little. 2014. Intake and growth of prepubertal dairy heifers fed reduced-fat dried distillers grains. Prof. Anim. Sci. 30:93-98. https://doi.org/10.15232/S1080-7446(15)30089-9.

$\mathrm{Su}, \mathrm{H}$. M. S., M. S. Akins, N. M. Esser, R. Ogden, W. K. Coblentz, K. F. Kalscheur, and R. Hatfield. 2017. Effects of feeding alfalfa stemlage or wheat straw for dietary energy dilution on nutrient intake and digestibility, growth performance, and feeding behavior of Holstein dairy heifers. J. Dairy Sci. 100:7106-7115. https://doi .org/10.3168/jds.2016-12448. 
Suarez-Mena, F. X., G. J. Lascano, and A. J. Heinrichs. 2013. Chewing activities and particle size of rumen digesta and feces of precision-fed dairy heifers fed different forage levels with increasing levels of distillers grains. J. Dairy Sci. 96:5184-5193. https://doi .org/10.3168/jds.2012-6155.

Suarez-Mena, F. X., G. J. Lascano, S. M. Hussein, and A. J. Heinrichs. 2019. Effects of distillers dried grains with solubles and forage dietary concentration in precision-fed dairy heifer diets: Mineral apparent absorption and retention. Appl. Anim. Sci. 35:169-176. https://doi.org/10.15232/aas.2018-01795.

Suarez-Mena, F. X., G. J. Lascano, D. E. Rico, and A. J. Heinrichs. 2015. Effect of forage level and replacing canola meal with dry distillers grains with solubles in precision-fed heifer diets: Digestibility and rumen fermentation. J. Dairy Sci. 98:8054-8065. https: //doi.org/10.3168/jds.2015-9636.

Tozer, P. R., and A. J. Heinrichs. 2001. What affects the costs of raising dairy heifers: A multiple component analysis. J. Dairy Sci. 84:1836-1844. https://doi.org/10.3168/jds.S0022-0302(01)74623 $-1$.

White, R. R., and J. L. Capper. 2014. Precision diet formulation to improve performance and profitability across various climates: Modeling the implications of increasing dairy cattle diet formulation frequency. J. Dairy Sci. 97:1563-1577.

Zanton, G. I., and A. J. Heinrichs. 2005. Meta-analysis to assess effect of prepubertal average daily gain on Holstein heifers on firstlactation production. J. Dairy Sci. 88:3860-3867. https://doi.org/ 10.3168/jds.S0022-0302(05)73071-X.

Zanton, G. I., and A. J. Heinrichs. 2007. The effects of controlled feeding of a high-forage or high-concentrate ration on heifer growth and first-lactation milk production. J. Dairy Sci. 90:3388-3396. https://doi.org/10.3168/jds.2007-0041.

Zanton, G. I., and A. J. Heinrichs. 2008. Analysis of nitrogen utilization and excretion in dairy cattle. J. Dairy Sci. 91:1519-1533. https://doi.org/10.3168/jds.2007-0624.

Zanton, G. I., and A. J. Heinrichs. 2009a. Digestion and nitrogen utilization in dairy heifers limit-fed a low or high forage ration at four levels of nitrogen intake. J. Dairy Sci. 92:2078-2094. https://doi .org/10.3168/jds.2008-1712.

Zanton, G. I., and A. J. Heinrichs. 2009b. Review: Limit-feeding with altered forage-to-concentrate levels in dairy heifer diets. Prof. Anim. Sci. 25:393-403. https://doi.org/10.15232/S1080 $-7446(15) 30740-3$

Zanton, G. I., and A. J. Heinrichs. 2016. Efficiency and rumen responses in younger and older Holstein heifers limit-fed diets of differing energy density. J. Dairy Sci. 99:2825-2836. https://doi .org/10.3168/jds.2015-10316.

\section{ORCIDS}

P. S. Erickson () https://orcid.org/0000-0002-8028-3279

J. L. Anderson ๑ https://orcid.org/0000-0001-7590-0749

K. F. Kalscheur @ https://orcid.org/0000-0002-5290-3602

G. J. Lascano (®) https://orcid.org/0000-0002-9052-7935

M. S. Akins @ https://orcid.org/0000-0001-5517-1681

A. J. Heinrichs (ㅇ https://orcid.org/0000-0001-5217-473X 